\author{
SHAMILOV E. N. ${ }^{1}{ }^{1}$, ABDULLAEV A. S. ${ }^{1}$, SHAMILLI V. E. ${ }^{1}$, AZIZOV I. V. ${ }^{2}$ \\ ${ }^{I}$ Institute of Radiation Problems of ANAS, \\ Azerbaijan Republic, AZ1143, Baku, B. Vahabzadeh str., 9, e-mail: elshanshamil@gmail.com \\ ${ }^{2}$ Institute of Molecular Biology and Biotechnology of NAS of Azerbaijan, \\ Azerbaijan, AZ1073, Baku,PR., Matbuat, 2A, e-mail: ibrahim.azizov47@gmail.com \\ 凶elshanshamil@gmail.com
}

\title{
ANTIRADIATION PROPERTIES OF EXTRACTS FROM HYPERICUM PERFORATUM L.
}

Aim. Considering the high biological activity of the components of the St. John's wort, we conducted studies to identify its radioprotective effect. Methods. Studies were conducted on adult Vistar rats with an average weight of 100-120 grams.3 hours before irradiation, the extract from St. John's wort was intraperitoneally administered to animals at a concentration of $50 \mathrm{mg} / \mathrm{kg}$. Irradiation was carried out once with doses of 5 and $7 \mathrm{~Gy}$ on the "Rhund-20000" facility with an average radiation dose rate $\mathrm{MD}=0.3069 \mathrm{Gr} / \mathrm{s}$. The frequency of chromosomal abnormalities was recorded on the mitotic cells of the bone marrow. Results. Acute irradiation with a dose of 5 Gy led to cell division inhibition. The number of chromosomal aberrations increased due to structural disorders (deletions, fragments, inversions) up to $6.8 \%$.In animals that received a dose of 7 Gy after a single irradiation, the frequency of chromosomal abnormalities increased to $11.02 \%$. The introduction of the Hypericum perforatum L. extract softened the effect of ionizing radiation, reducing the mutational effect of radiation. It not only contributed to the restoration of the cell division, but also reduced the proportion of structural disorders. Conclusions. Hypericum extract can be considered to be promising as an anti-radiation agent of plant origin.

Keywords: rats, chromosomal abnormalities, marrow, irradiation, extract.

In recent year's scientists and physicians give much attention to studying the nature of biological activity of individual components of plant materials and their mechanism of action on a living organism. At the same time improving methods of isolation and purification of biologically active compounds, various modifications are carried out, that aimed to get the drug with predetermined therapeutic properties to ensure the strengthening of human health.

Under the influence of adverse environmental factors (including radiation), decreases the resistance of the body. By reducing the body's resis- tance against the all adverse environmental factors radiation also affects the immune system, which in turn is provided to be a general weakness, susceptibility to various diseases.

In this case, there may help medicinal plants that belong to a group that generally strengthen the body. Means that improve the overall resistance of the body, improve the natural radioresistance of the organism. As a rule, they are administered a few days or hours prior to irradiation in amounts that do not produce, any hazardous, toxic effects. [1]. The protective action of these compounds is most pronounced during irradiation, causing the death of 20$70 \%$ of the animals. Among the most effective means in this group include lipopolysaccharides, polyphenol complex, flavonoids, terpene saponins, a combination of amino acids and vitamins, etc. The introduction of such compounds to animals before the irradiation facilitates radiation sickness, increases survival, reduces the degree of metabolic imbalance processes, and hematopoiesis etc. The protective effect of these means is probably due to increased activity of the pituitary-adrenocortical axis system, increasing the ability of hematopoietic cells to multiply, stimulation of reticuloendothelial system, increased immunological reactivity of an organism and etc. These means speed up the process of protein and nucleic acids synthesis in the cells that contribute to the restoration of unique genetic structure. There is evidence indicating the ability of these means to increase the body's resistance not only against radiation but also against other pathogenic influences.

In conditions of prolonged irradiation of animals at the exposure dose rate below $1 \mathrm{R} / \mathrm{min}$ even the most effective radioprotectors do not have a prophylactic effect. Just why special attention should be paid to a new data on the effectiveness of means in these conditions that promote reparation of unique genetic structure.

Under the influence of radioprotective substances of plant origin in the irradiated animals ne-

\footnotetext{
${ }^{\circ}$ SHAMilOV E. N., ABDULlAEV A. S., SHAMilli V. E., AZIZOV I. V.
} 
crobiotic processes weaken in the hemopoietic organs and intestines, reducing the number of cells with chromosomal rearrangements, there is a more rapid recovery of mitotic activity. This is due to interference of radioprotective substances in the primary physical and chemical processes of radiation damage (interception of reactive free radicals).

In earlier studies we widely investigated the radioprotective effect of extracts derived from medicinal plants of Azerbaijan [2-10].

St. John's wort (Hypericum perforatum L.) is widely used to treat diseases of the biliary tract, hepatitis, cholecystitis, gastritis with secretory insufficiency, flatulence, as well as reducing the filtration capacity of the kidneys.

In consideration of the high biological activity of constituents of $H$. perforatum, we conducted research to identify its radioprotective influence. The composition of St. John's wort contains the following active substances: flavonoids (hyperoside, rutin, hypericin, pseudohypericin, hyperforin, quertsitrin, isoquertsitrin and quercetin), fluorescent, dyes substances and tannins, carotene, essential oils, resins, niacin and ascorbic acid, vitamin $\mathrm{P}$ and PP, choline, anthocyanins, saponins, alcohols, traces of alkaloids and other compounds.

\section{Materials and methods}

To study radioprotective properties we have obtained an extract of $H$. perforatum. Usually in medical practice there is used alcoholic extracts of biologically active substances, for both internal and external use. Extraction was carried out in alcoholic solution, when boiled with a reverse ball refrigerator. Evaporation of the solvent was carried out in vacuum on a rotary evaporator at $30-40^{\circ} \mathrm{C}$ until mushy residue.

The study was performed on adult Wistar rats of average weight $100-120$ grams. 15 animals $(6$, $9 \hat{\jmath})$ took part in experiments. 3 hours before irradiation, the animals were injected intraperitoneally with Hypercom extract in a concentration of $50 \mathrm{mg} / \mathrm{kg}$. The irradiation was performed once in doses of 5 and 7 Gy at the "Rhund-20000" with an average radiation dose $\mathrm{MD}=0,3069 \mathrm{~Gy} / \mathrm{sec}$. Slaughter of animals was performed one day after irradiation. The frequency of chromosomal aberrations was recorded on mitotic cells of the bone marrow. Preparations of bone marrow obtained by the method of Ford and Hamerton [11]. Staining was performed according to Rajabli, Kryukova [12], Howell, Black [13]. Selection of plates was carried out according to the criteria proposed by Drum and colleagues [14] and Zakharov [15].

\section{Results and discussions}

For analysis of chromosome sets used microscope "Amplival." Photomicrography was carried out automatically by photo attachment MF (lens $\mathrm{x} 100$, eyepiece $\mathrm{x} 4,1$ Prohectiv). For every animal investigated at least 250 metaphase plates of bone marrow (Table 1).

Cytogenetic analysis of bone marrow cells in control white rats revealed no structural chromosome damages. The frequency of aberrations was $0.54 \%$. These were mostly quantitative disorders such as polyploid and aneuploid plates. Introduction of $H$. perforatum extract did not make any effect on the magnitude of spontaneous mutations (Table 2).

Table 1. Type of effects, and characteristics of the investigated material

\begin{tabular}{|c|c|c|}
\hline Type of exposure & $\begin{array}{l}\text { Number of examined } \\
\text { rats }\end{array}$ & $\begin{array}{l}\text { Number of studied mi- } \\
\text { totic cells }\end{array}$ \\
\hline Intact Control & $2 \hat{\jmath}+1$ ㅇ & 560 \\
\hline$\Gamma$-irradiation 5 Gy & $1 \hat{0}+1$ ㅇ & 573 \\
\hline$\Gamma$ - irradiation $7 \mathrm{~Gy}$ & $1 \hat{\jmath}+1$ + & 544 \\
\hline Hypericum perforatum L. extract & $1 \hat{\jmath}+1$ ㅇ & 645 \\
\hline Hypericum perforatum $+5 \mathrm{~Gy}$ & $2 \hat{\jmath}+19$ & 594 \\
\hline Hypericum perforatum $+7 \mathrm{~Gy}$ & $2 \hat{o}+1$ ㅇ & 495 \\
\hline
\end{tabular}

Note. $\mathrm{P}<0,001$. 
Antiradiation properties of extracts from Hypericum perforatum L.

Table 2. Effect of $H$. perforatum extract on the frequency of chromosomal aberrations in bone marrow cells of albino rats

\begin{tabular}{|c|c|c|c|c|c|c|}
\hline Variants & $\begin{array}{c}\text { Number of } \\
\text { metaphases } \\
\text { (total) }\end{array}$ & $\begin{array}{c}\text { Number of } \\
\text { metaphases- } \\
2 \mathrm{n}=42\end{array}$ & $\begin{array}{c}\text { Polyploid } \\
\text { metaphases }\end{array}$ & $\begin{array}{c}\text { Aneuploid } \\
\text { metaphases }\end{array}$ & $\begin{array}{c}\text { Structural } \\
\text { disorders }\end{array}$ & $\begin{array}{c}\% \text { of dis- } \\
\text { orders }\end{array}$ \\
\hline Intact control & 560 & 572 & 2 & $1(\mathrm{n}>42)$ & - & 0,54 \\
\hline Irradiation 5Gy & 573 & 555 & 9 & $\begin{array}{c}7(\mathrm{n}>42) \\
4(\mathrm{n}<42)\end{array}$ & 14 & 6,8 \\
\hline Irradiation 7Gy & 544 & 612 & 16 & $\begin{array}{c}9(\mathrm{n}>42) \\
6(\mathrm{n}<42)\end{array}$ & 29 & 11,02 \\
\hline $\begin{array}{c}\text { H. perforatum ex- } \\
\text { tract }\end{array}$ & 645 & 589 & 2 & $\begin{array}{c}1(\mathrm{n}>42) \\
1(\mathrm{n}<42)\end{array}$ & 1 & 0,78 \\
\hline $\begin{array}{c}\text { H. perforatum ex- } \\
\text { tract + 5 Gy }\end{array}$ & 594 & 613 & 7 & $\begin{array}{c}3(\mathrm{n}>42) \\
5(\mathrm{n}<42)\end{array}$ & 9 & 4,04 \\
\hline $\begin{array}{c}\text { H. perforatum. ex- } \\
\text { tract + 7 Gy }\end{array}$ & 495 & 523 & 12 & $\begin{array}{c}5(\mathrm{n}>42) \\
8(\mathrm{n}<42)\end{array}$ & 20 & 9,1 \\
\hline
\end{tabular}

Note. $\mathrm{p}<0,001$.

Acute exposure in a dose of 5 Gy resulted in inhibition of cell division. Due to structural defects (deletions, fragments, inversions) number of chromosomal aberrations increased up to $6,8 \%$. In the animals that received a dose of $7 \mathrm{~Gy}$ in a single irradiation frequency of chromosomal abnormalities increased up to $11.02 \%$. In this case there was observed a sharp increase of ring chromosomes, dicentrics, and fragments of single mitotic cells in the bone marrow.

Inhibition of cell division is the result of exposure to ionizing radiation doses. With increasing doses of radiation there are more cells losing their ability to divide or at least they stopped the fission process, which leads to the appearance of polyploid cells. So, in animals irradiated with a dose of $7 \mathrm{~Gy}$ dramatically increased the number of tetraploid and octoploid cells. However, the percentage of structural chromosomal disorders was higher than in the control experiments, and lower than in experiments with acute irradiation. The highest percentage of violations was observed when animals were irradiated in a dose of $7 \mathrm{~Gy}$.

Analysis of germ cells showed their significant sensitivity to influence of acute exposure. These cells were much more sensitive than bone marrow cells, almost 3 times. Increased number of spermatocytes with signs of degeneration, increased frequency of violations of conjugation between $\mathrm{X}$ and $\mathrm{Y}$ chromosomes. It was also noted an increase in polyploid and aneuploid meiotic plates at metaphase I and metaphase II.

Introduction of $H$. perforatum extract mitigated the effects of ionizing radiation, by reducing the mutational effects of radiation. Little inhibition of cell division observed. It is not only contributed to the restoration of cell division, but also reduced the proportion of structural defects (Table 2).

We have also conducted experiments where animals received Hypericum extract after irradiation. Terms and administration of the extract remained, as in the administration of the extract prior to irradiation. It was found that the introduction of the extract after gamma irradiation also mitigated the effects of ionizing radiation: the percentage of structural chromosomal disorders was higher than in unexposed control options, and lower - in the versions with acute irradiation.

\section{Conclusions}

In our opinion, an extract of hypericum can be considered as a promising radioprotective mean of plant origin. Further researches on identifying more effective concentrations and genetic effects caused by chronic irradiation with introduction of multiple doses of hypericum extract may be present a great interest.

The work was supported by the STCU Grant No. 6282. 


\section{References}

1. Yarmonenko S.P. Antiradiation protection of the body. M., 1969.

2. Aliev R.K., Prilipko L.I., Damirov I.A. Medicinal Plants of Azerbaijan; Directory. Baku: Azerbaijan State Publishing House, 1972.

3. Shamilov E.N., Abdullayev A.S., Rzayeva I.A., Azizov I.V. Influence of iron complexes on the formation of photosynthetic apparatus and yield of genetic changes in gamma-irradiated wheat seeds. Visnyk of Dnipropetrovsk University. Biology. Medecine. 2010. Vol. 18, No. 2. P. 90-95.

4. Azizov I.V., Abdullayev A.S., Shamilov E.N., Rzayev A.A., Akhmedov I.D. Effect of Hypericum extract (Hypericum perforatum L.) and peganum (Peganum harmala L.) on growth of wheat seedlings. "Proceedings of the Institute of Botany of NAS of Azerbaijan". Baku: "Elm", 2007. Vol. XXVII. P. 182-184.

5. Mamedov N.A., Rzayev A.A., Shamilov E.N., Abdullaev A.S., Craker L.E. Radioprotective activity of some medicinal plant extracts. Acta Hort. (ISHS). 2011. 925. P. 315-320. URL: http://www.actahort.org/books/925/925_46.htm (Last accessed: 5.03.2019).

6. Kasumov F.Y., Shamilov E.N., Abdullayev A.S., Kasumova N.I., Kuliev G.N. Investigation of the component composition of the extract of saffron (Crocus sativus L.) and its antiradiation action. Russia. Supplement to the magazine "Traditional Medicine". 2010. № 3 (22). P. 140-146.

7. Shamilov E.N., Abdullaev A.S., Akhmedov I.D., Azizov I.V. Study of antiradiation properties of polymer-modified extract of Hypericum perforatum L. Radiobiological and radioecological aspects of the Chernobyl disaster: abstracts of International Conference. Slavutych, 2011. P. 149.

8. Shamilov E.N. Comparative study of the impact of phytocomposition extract on some blood characteristics of irradiated rats. International Journal of Pharmaceutical Science and Health Care. 2015. Issue 5, Vol. 3. P. 118-121. URL: http://www.rspublication.com/ijphc/index.html ISSN 2249 - 5738 (Last accessed: 5.03.2019).

9. Shamilov E.N., Rzayev A.A., Abdullayev A.S., Kasumova N.I., Kuliev G.N., Mamedrzayeva E.T., Gaza A.G., Azizov I.V. Cytogenetic changes of irradiated rats under the influence of plant biocomplexes. Proceedings of the Georgian Academy of Sciences, Biological Series A. Tbilisi, 2009. Vol. 35. P. 393-401.

10. Azizov I., Shamilov E., Abdullayev A., Muslimova Z., Mamedli G., Gasimova G. Influence of a Modified Plant Extract on Activity of Antioxidant Enzymes and Concentration of Pigments in Gamma-Irradiated Plants of Maize and Wheat. Proceedings of the Latvian Academy of Sciences. Section B. Natural, Exact, and Applied Sciences. 2018. Vol. 72, № 1. P. 38-42.

11. Ford C.E., Hamerton J.L. A colchicines hypotonic citrate squash sequence for mammalian chromosomes. Stain Technol. 1956. Vol. 31. P. 247-251.

12. Rajabli S.I., Kryukova E. The comparative analysis of the differential staining of chromosomes of two species of hamsters, Chinese and Daurian. Cytology. 1973. Vol. 15. P. 1527-1531.

13. Howell W.M., Dlack D.A. Controlled silver staining of nucleolus organizer regions with a protective colloidal developer: in a one step method. Experientia. 1980. Vol. 36. P. 1014-1015.

14. Bochkov N.P., Kozlov V.M., Sevankaev A.V., Antoshina M.M. Analysis of aneuploidy in cultures of embryonic human fibroblasts. Genetics. 1966. № 10. P. 120-124.

15. Zakharov A.F. Human chromosomes. Problems of linear organization. 1977. P. 2-192.

ШАМІЛОВ Е. Н. ${ }^{1}$, АБДУЛЛАЄВ А. С. ${ }^{1}$ ШАМІЛЛІ В. Е. ${ }^{1}$, АЗІЗОВ І. В. ${ }^{2}$

${ }^{l}$ Інститут радіаційних проблем Національної Академії Наук Азербайджану, Азербайджан, AZ1143, м. Баку, вул. Б. Вагабзаде, 9, e-mail: elshanshamil@ gmail.com

${ }^{2}$ Інститут молекулярної біології та біотехнології Наиіональної Академії Наук Азербайджану, Азербайджан, AZ1073, м. Баку, пр. Матбуат, 2A, e-mail: ibrahim.azizov47@gmail.com

\section{АНТИРАДІАЦІЙНI ВЛАСТИВОСТІ ЕКСТРАКТІВ 3 HYPЕRICUM PERFORATUM L.}

Mema. 3 огляду на високу біологічну активність складових компонентів звіробою звичайного, нами були проведені дослідження з виявлення його протипроменевої дії. Методи. Дослідження проводили на статевозрілих щурах лінії Vistar середньою вагою 100-120 грам. За 3 години до опромінення тваринам внутрішньоочеревинно вводили екстракт звіробою в концентрації 50 мг/кг. Опромінення проводилося однократно дозами в 5 і 7 Гр на установці "Рхунд-20000" при середній потужності дози випромінювання $\mathrm{MD}=0,3069$ Гр / сек. Частоту хромосомних порушень реєстрували на мітотичних клітинах кісткового мозку. Результати. Гостре опромінення дозою в 5 Гр призводило до пригнічення клітинного поділу. Збільшувалося число хромосомних аберацій за рахунок структурних порушень (делецій, фрагментів, інверсій) до 6,8\%. У тварин, які отримали дозу в 7 Гр при одноразовому опроміненні частота хромосомних порушень зростала до $11,02 \%$. Введення екстракту Нурегісит perforatum L. пом'якшувало дію іонізуючого випромінювання, знижуючи мутаційний ефект радіації. Він не тільки сприяв відновленню клітинного поділу, а й зменшував частку структурних порушень. Висновки. Екстракту звіробою можна вважати перспективним в якості протипроменевого засобу рослинного походження.

Ключові слова: пацюки, хромосомні порушення, кістковий мозок, опромінення, екстракт. 